\title{
Operative implications of the small aortic root
}

\author{
LM Lucuta ${ }^{1 *}$, SL Mosteoru', M Gaspar ${ }^{1,2}$, H Feier $^{1,2}$ \\ From International Conference for Healthcare and Medical Students 2011 \\ Dublin, Ireland. 4-5 November 2011
}

\section{Introduction}

Replacement of the aortic valve with a mechanical prosthesis when the annular diameter is small, meaning $21 \mathrm{~mm}$ or less, can present significant hemodynamic and technical problems, including patient-prosthesis mismatch and persistent heart failure. The aim of this paper is to assess the operative implications of the small aortic root during surgery.

\section{Methods}

Our study comprises of 46 patients operated during the last 3 years in the IInd Cardiovascular Surgery Department who received 19 and $21 \mathrm{~mm}$ aortic valves. There were 20 males (43.48\%) and 26 females (56.52\%) in our cohort. The mean age was 57 years (ranging from 17 to 78 ). The most frequent diagnosis was degenerative aortic stenosis (59\%) followed by rheumatic aortic disease (22\%). The preoperative indexed aortic valve orifice was $0.58 \mathrm{~cm}^{2} / \mathrm{m}^{2}$ and the mean maximum transaortic gradient was $82 \mathrm{~mm} \mathrm{Hg}$. The follow-up period was around $22.58 \pm 12.19$ months.

\section{Results}

There were 3 deaths out of which 2 were intraoperative in our series (6.52\% and $4.35 \%$, respectively). All had $19 \mathrm{~mm}$ valves implanted, of which one after aortic annulus enlargement and their theoretical indexed effective orifice area was smaller than $0.65 \mathrm{~cm}^{2} / \mathrm{m}^{2}$ in all cases. A total of $8(17.39 \%)$ patients had $19 \mathrm{~mm}$ valves and $38(82.61 \%)$ had $21 \mathrm{~mm}$ prosthetic valves.

\section{Conclusions}

The small aortic root is a serious operative risk. Based on the available valve types and preoperative body surface area the minimal recommended prosthesis size can be determined. Enlargement of the aortic annulus should be considered more frequently in these cases.

"Victor Babeş" University of Medicine and Pharmacy, Timişoara, Romania Full list of author information is available at the end of the article

\section{Author details}

"Victor Babeş" University of Medicine and Pharmacy, Timişoara, Romania.

${ }^{2}$ Timişoara Institute of Cardiovascular Medicine, Ind Cardiovascular Surgery Department, Romania.

Published: 9 July 2012

doi:10.1186/1753-6561-6-S4-P4

Cite this article as: Lucuta et al:: Operative implications of the small aortic root. BMC Proceedings 2012 6(Suppl 4):P4.
Submit your next manuscript to BioMed Central and take full advantage of:

- Convenient online submission

- Thorough peer review

- No space constraints or color figure charges

- Immediate publication on acceptance

- Inclusion in PubMed, CAS, Scopus and Google Scholar

- Research which is freely available for redistribution
C Biomed Central 